\title{
GREEN MANURE IN COFFEE SYSTEMS IN THE REGION OF ZONA DA MATA, MINAS GERAIS: CHARACTERISTICS AND KINETICS OF CARBON AND NITROGEN MINERALIZATION ${ }^{(1)}$
}

\author{
Eduardo da Silva Matos ${ }^{(2)}$, Eduardo de Sá Mendonça ${ }^{(3)}$, Paulo César de \\ Lima $^{(4)}$, Marino Salgarello Coelho ${ }^{(5)}$, Renato Faria Mateus ${ }^{(5)} \&$ Irene \\ Maria Cardoso ${ }^{(3)}$
}

\begin{abstract}
SUMMARY
The use of green manure may contribute to reduce soil erosion and increase the soil organic matter content and $\mathrm{N}$ availability in coffee plantations in the Zona da Mata, State of Minas Gerais, in Southeastern Brazil. The potential of four legumes (A. pintoi, C. mucunoides, S. aterrimum and S. guianensis) to produce above-ground biomass, accumulate nutrients and mineralize $\mathrm{N}$ was studied in two coffee plantations of subsistence farmers under different climate conditions. The biomass production of $C$. mucunoides was influenced by the shade of the coffee plantation. C. mucunoides tended to mineralize more $\mathrm{N}$ than the other legumes due to the low polyphenol content and polyphenol/N ratio. In the first year, the crop establishment of $A$. pintoi in the area took longer than of the other legumes, resulting in lower biomass production and $\mathrm{N}_{2}$ fixation. In the long term, cellulose was the main factor controlling $\mathbf{N}$ mineralization. The biochemical characteristics, nutrient accumulation and biomass production of the legumes were greatly influenced by the altitude and position of the area relative to the sun.

Index terms: agroecology, Atlantic Forest, leguminous species, $\mathrm{N}_{2}$ fixation, nutrient cycling.

\footnotetext{
(1) Parta da Tese de Doutorado do primeiro autor apresentada a Universidade Federal de Viçosa - UFV. Recebido para publicação em janeiro de 2008 e aprovado em julho de 2008.

(2) $\mathrm{PhD}$ Student, Chair of Soil Protection and Recultivation, Brandenburg University of Technology, Cottbus, 03046, Germany. E-mail: matos@tu-cottbus.de

(3) Professor do Departamento Solos, Universidade Federal de Viçosa - UFV. Av. PH Rolfs s/n, CEP 36570-000 Viçosa (MG). E-mails: esm@ufv.br; irene@ufv.br

(4) Pesquisador, EPAMIG - Instituto de Pesquisa de Minas Gerais. Vila Gianetti 46, CEP 36570-000 Viçosa (MG).

(5) Estudante de Agronomia do Departamento Solos, UFV.
} 


\title{
RESUMO: ADUBOS VERDES EM CAFEZAIS NA ZONA DA MATA DE MINAS GERAIS: CARACTERÍSTICAS E CINÉTICAS DE MINERALIZAÇÃO DE CARBONO E NITROGÊNIO
}

\begin{abstract}
O uso de adubos verdes pode contribuir para a redução da erosão do solo, o aumento da sua matéria orgânica e a disponibilidade de $N$ para o café produzido na Zona da Mata de Minas Gerais. Objetivou-se avaliar o potencial de produção de biomassa, acúmulo de nutrientes e mineralização de $N$ de quatro leguminosas (Arachis pintoi, Calopogonium mucunoides, Stylozanthes guyanensis e Stizolobium aterrimum) cultivadas nas entrelinhas de café sob diferentes condições edafoclimáticas. A produção de biomassa de C. mucunoides foi influenciada pelo sombreamento do café. Houve tendência de maior mineralização de $N$ para C. mucunoides, comparado com as outras leguminosas, em razão das menores concentrações de polifenóis e da relação polifenol/N. Por ocasião do primeiro corte, A. pintoi apresentou baixa produção de biomassa e fixação de N. A longo prazo, o teor de celulose foi o principal fator controlador da mineralização de N. As características bioquímicas, o acúmulo de nutrientes e a produção de biomassa foram altamente influenciados pela altitude e orientação das áreas de estudo em relação ao sol.
\end{abstract}

Termos de indexação: agroecologia, Floresta Atlântica, leguminosa, fixação de $\mathrm{N}_{2}$, ciclagem de nutrientes.

\section{INTRODUCTION}

The region Zona da Mata of Minas Gerais in Southeastern Brazil is hilly and soils are highly weathered, acidic, with low nutrient concentrations available to plants. Family agriculture with little external inputs such as fertilizers is characteristic for this region. Coffee is the main cash crop, but the production of other crops is vital as subsistence source (Ferrari, 1996).

Erosion control and increased agro-biodiversity are required to improve the bio-physical-chemical soil processes to ensure sustainable agriculture in the region. Enhancing biodiversity through legume fertilization may contribute to reduce soil erosion, maintain or increase quantity and quality of soil organic matter, provide a $\mathrm{N}$ source for coffee, reduce the demand for mineral N (Sá \& Vargas, 1997), and improve soil quality and nutrient cycling.

The success of green manure in maintaining soil quality and increasing nutrient cycling depends on the soil type, management system, geographic location and cultivation period (Thönnissen et al., 2000). Other factors are the amount and quality of the residue produced, the nutrient amount released through residue decomposition, and the temporary synchrony between the nutrient release by decomposition and crop requirements. Among the many legume species used as green manure, Stizolobium aterrimum, Arachis pintoi, Calopogonium mucunoides and Stylosanthes guianensis stand out owing to the ability to produce high amounts of biomass and to accumulate high nutrient concentrations, even in soils with low natural fertility and high acidity, besides the atmospheric $\mathrm{N}_{2}$ fixation capacity (Aita et al., 2000;
Niang et al., 2002; Muhr et al., 2002; Borkert et al., 2003; Perin et al., 2003).

Residue mineralization rates depend on the quality of plant residues, environmental temperature, pluvial precipitation, and soil characteristics such as clay mineralogy, acidity, biological activity, and nutrient availability (Thönnissen et al., 2000). When environmental conditions are not limiting, the chemical and biochemical composition of plant residues are the main factors affecting decomposition (Trinsoutrot et al., 2000). Nitrogen mineralization is highly influenced by the C:N ratio (Cabrera et al., 2005) as well as by the polyphenolic content and polyphenol:N ratio, especially during the first week of residue decomposition (Mafongoya et al., 1998; Trinsoutrot et al., 2000). Polyphenols form a complex with proteins and can consequently reduce $\mathrm{N}$ availability to microorganisms (Hättenschwiler \& Vitousek, 2000). In the long term, C and N mineralization are affected by more recalcitrant components, such as cellulose (Hadas et al., 2004) and lignin (Palm \& Sanchez, 1991; Manfongoya et al., 1998), and the lignin:N ratio (Palm \& Sanchez, 1991).

Despite the increasing experience with legumes in the tropics, there is a lack of information about the performance in areas under coffee shade and the $\mathrm{N}$ release potential in organic coffee systems. This study was carried out to evaluate the biomass production and nutrient accumulation of A. pintoi, $C$. mucunoides, $S$. aterrimum and $S$. guianensis as green manure in two experimental areas of organic coffee under two climate conditions in the southeastern region of Brazil. The potential of these plants to mineralize $\mathrm{C}$ and $\mathrm{N}$ was also evaluated under controlled laboratory conditions. 


\section{MATERIAL AND METHODS}

Green manure (A. pintoi, C. mucunoides, $S$. aterrimum and $S$. guianensis) was cultivated in two experimental areas with coffee on two small farms (family farming) in two municipalities of the region Zona da Mata, Minas Gerais, Brazil, from December 2003 to April 2004. The experiment was a joint project of the Universidade Federal de Viçosa, the Empresa de Pesquisa Agropecuária de Minas Gerais (EPAMIG) and the Centro de Tecnologia Alternativa of Zona da Mata (NGO). One of the experimental plots was outlined on a farm in Araponga (20 $38^{\circ}$ ' S latitude, $42^{\circ} 31^{\prime} \mathrm{W}$ longitude, altitude $950 \mathrm{~m}$, highest mean annual temperature $25.4{ }^{\circ} \mathrm{C}$, lowest $13.7^{\circ} \mathrm{C}$, precipitation $1.320 \mathrm{~mm}$ ), facing west. On the other farm, in Pedra Dourada (20 $0^{\circ} 50^{\prime}$ S latitude, $42^{\circ} 08^{\prime}$ W longitude, altitude of $690 \mathrm{~m}$, highest mean annual temperature $27.6{ }^{\circ} \mathrm{C}$, lowest $16.2^{\circ} \mathrm{C}$, precipitation $1.280 \mathrm{~mm}$ ) the experimental plot was established facing South. The soils of both sites were classified as Latossolo Vermelho-Amarelo (Red-Yellow Latosol) by the Brazilian and as a Typic Haplustox by the U.S. soil taxonomy system (Table 1).

Before planting the green manure crops, fertilizer and lime were applied between the coffee rows. Subsequently, the four green manure species were planted between the rows of three-year-old organic coffee in experimental plots $(3.0 \times 0.8 \mathrm{~m})$. Per ha, $0.26 \mathrm{t}$ lime, $64 \mathrm{~kg}$ gypsum, $125 \mathrm{~kg}$ potassium sulphate and $800 \mathrm{~kg}$ termophosphate were applied in Araponga. In Pedra Dourada, 1.20 t lime, $300 \mathrm{~kg}$ gypsum, $125 \mathrm{~kg}$ potassium sulphate and $800 \mathrm{~kg}$ termophosphate were applied per ha. All legumes were grown from seeds (not inoculated with Rhizobium), planted at about 1 cm depth. Approximately 120 days after sowing, the above-ground parts of the legumes were collected and weighed. A sample of the above-ground parts was dried $\left(55^{\circ} \mathrm{C}\right)$ to measure the water content and for chemical analyses. The experiment was arranged in a completely randomized block design with a factorial arrangement of $2 \times 4$ (two sites and four legume species), with four replications per site.

Dried above-ground material was ground and sieved $(<1 \mathrm{~mm})$. Total $\mathrm{C}$ and $\mathrm{N}$ were analyzed through dry combustion (Perkin Elmer CHNS/O 2400). Total $P$ was analyzed by the molybdenum blue method (Braga \& Defelipo, 1994) after digestion with perchloric and nitric acids (Sarruge \& Haag, 1974), $\mathrm{Ca}$ and $\mathrm{Mg}$ were analyzed using the same acid digestion solution in an atomic absorption spectrophotometer and $\mathrm{K}$ was analyzed using a flame spectrophotometer. Total nutrient quantities in the residues were calculated by multiplication of the concentrations in the dry biomass per hectare. Soluble polyphenols were extracted with $50 \%$ aqueous methanol and the final concentration was analyzed colorimetrically using the Folin-Denis reagent with tannic acids as standard (Anderson \& Ingram, 1996). Lignin, cellulose and hemicellulose contents were analyzed by the aciddetergent fiber method (van Soest et al., 1991).

The amount of $\mathrm{C}-\mathrm{CO}_{2}$ produced (mineralizable $\mathrm{C}$ ) was measured in a $480 \mathrm{~h}$ incubation experiment in a continuous air flux (Curl \& Rodriguez-Kabana, 1972) with four replications for each of the four legume species, arranged in a completely randomized design. The B horizon of a clayey Typic Haplustox soil (Table 1) was used for incubation. The soil was sieved $(<2 \mathrm{~mm})$ to remove roots and organic debris. Leaves of each legume species, equivalent to $2 \mathrm{~g} \mathrm{C}$, were mixed with $100 \mathrm{~g}$ soil and filled into incubation flasks $(377 \mathrm{~mL})$. Double-deionized water was added up to $70 \%$ field capacity. All flasks were incubated at $25 \pm 1^{\circ} \mathrm{C}$. The C- $\mathrm{CO}_{2}$ emission was trapped with $0.5 \mathrm{~mol} \mathrm{~L}^{-1} \mathrm{NaOH}$ and titrated with $0.25 \mathrm{~mol} \mathrm{~L}-1 \mathrm{HCl}$. Carbon- $\mathrm{CO}_{2}$ measurements were performed eight times, the first five at $48 \mathrm{~h}$ intervals, then two at $72 \mathrm{~h}$ intervals and finally one after $96 \mathrm{~h}$.

Table 1. Soil chemical and physical characteristics in the 0-20 cm layer in Araponga and Pedra Dourada, used for incubation experiments

\begin{tabular}{|c|c|c|c|}
\hline Chemical characteristics & Araponga & Pedra Dourada & Incubation experiment \\
\hline $\mathrm{pH}(1: 2,5)$ & 5.24 & 5.04 & 4.2 \\
\hline $\mathrm{Al}^{3+}\left(\mathrm{cmol}_{\mathrm{c}} \mathrm{dm}^{-3}\right)^{(1)}$ & 0.47 & 0.59 & 1.37 \\
\hline $\mathrm{P}\left(\mathrm{mg} \mathrm{dm^{-3 }}\right)^{(1)}$ & 1.00 & 2.92 & 0.50 \\
\hline $\mathrm{K}\left(\mathrm{mg} \mathrm{dm} \mathrm{m}^{-3}\right)^{(1)}$ & 59.8 & 53.5 & 11.0 \\
\hline $\mathrm{Ca}^{2+}\left(\mathrm{cmol}_{\mathrm{c}} \mathrm{dm}^{-3}\right)^{(2)}$ & 1.74 & 0.99 & nd \\
\hline $\mathrm{Mg}^{2+}\left(\mathrm{cmol}_{\mathrm{c}} \mathrm{dm}^{-3}\right)^{(2)}$ & 0.74 & 0.47 & 0.03 \\
\hline Organic $\mathrm{C}\left(\mathrm{g} \mathrm{kg}^{-1}\right)^{(3)}$ & 29.0 & 36.8 & 20.0 \\
\hline Total N ( $\left.\mathrm{g} \mathrm{kg}^{-1}\right)$ & - & & 1.5 \\
\hline \multicolumn{4}{|l|}{ Physical Characteristics } \\
\hline $\begin{array}{l}\text { Sand (\%) } \\
\text { Clay (\%) }\end{array}$ & $\begin{array}{l}39 \\
52\end{array}$ & $\begin{array}{l}36 \\
45\end{array}$ & $\begin{array}{l}30 \\
64\end{array}$ \\
\hline
\end{tabular}

(1) Mehlich-1. ${ }^{(2)} \mathrm{KCl} 1$ mol L-1. ${ }^{(3)}$ Walkley Black method; nd: not detected. 
The $\mathrm{C}-\mathrm{CO}_{2}$ production was calculated as function of time (Morgan et al., 1975):

$$
Y_{i}=\frac{a}{1+e^{-\left(b+c t_{i}\right)}}+\varepsilon_{i}
$$

with $\mathrm{Y}_{\mathrm{i}}=\mathrm{C}-\mathrm{CO}_{2} ; \mathrm{a}=\mathrm{C}-\mathrm{CO}_{2}$ saturation; $b=$ constant to achieve saturation; $c=$ constant of C- $\mathrm{CO}_{2}$ emission; $t=$ time $(\mathrm{h})$; and $\varepsilon=$ error.

The $t_{1 / 2}$, which expresses the mean time to achieve $\mathrm{C}-\mathrm{CO}_{2}$ saturation, was calculated as $-b / c$. The net $\mathrm{N}$ mineralization was also measured through incubation $\left(25 \pm 1^{\circ} \mathrm{C}\right)$ of leaves of each legume species (equivalent to $2 \mathrm{~g} \mathrm{C}$ ), mixed with $100 \mathrm{~g}$ of the soil in $500 \mathrm{~mL}$ flasks under anaerobic conditions. Double-deionized water was added to reach $70 \%$ of the field capacity. During seven weeks, N- $\mathrm{NH}_{4}{ }^{+}$and $\mathrm{N}-\mathrm{NO}_{3}{ }^{-}$were measured weekly colorimetrically in a $1 \mathrm{~mol} \mathrm{~L}^{-1} \mathrm{KCl}$ extract (Kempers \& Zweers, 1986; Yang et al., 1998).

Statistical analyses were performed using SAEG 5.0 (Funarbe, 1993). Analysis of variance (ANOVA), followed by a Tukey multiple comparison method $(p<0.05)$, was used to verify the differences among treatments of $\mathrm{C}-\mathrm{CO}_{2}$ and mineralized $\mathrm{N}$.

\section{RESULTS AND DISCUSSION}

\section{Biomass production of green manure}

The production of dry biomass (DB) of green manure varied between localities and among plant species on the same farm (Figure 1). A. pintoi produced the lowest amount of dry biomass at both sites. In Araponga, C. mucunoides and S. aterrimum and in Pedra Dourada, C. mucunoides and S. guianensis

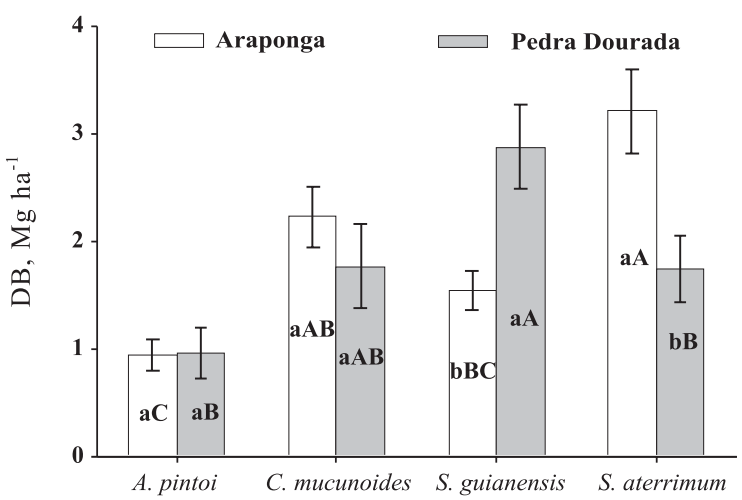

Figure 1. Average and standard error $(n=4)$ of the dry matter produced by the green manures on the farms in Araponga and Pedra Dourada. Same letters indicate no significant difference (Tukey 5\%). Capital letters compare species on the same farm and small letters compare the same species among farms. produced the highest amounts of DB. The differences in the amount of DB produced by the same species between the two sites shows that the species of green manure respond differently to different soil-climate conditions such as changes in temperature related with differences in altitude and the position of the agricultural area relative to the sun.

In the first year, the DB production was low for $A$. pintoi, C. mucunoides and $S$. aterrimum compared to results reported in the literature (Aita et al., 2000; Niang et al., 2002; Soares et al., 2006). However, A. pintoi and C. mucunoides are perennial plants and the production is expected to higher and more stable after the first year. The fact that these plants were not inoculated with Rhizobium, as well as the shade of the coffee trees may have affected the production of green manure biomass and may explain the differences between the values reported here and in the literature.

\section{Nutrients in green manure biomass}

In Araponga and in Pedra Dourada, S. aterrimum and $C$. mucunoides contained the highest $\mathrm{N}$ concentration (Table 2). Nitrogen contents were lowest in A. pintoi at both sites. In Araponga, S. aterrimum and $S$. guianensis contained most $\mathrm{P}\left(2.5 \mathrm{~g} \mathrm{~kg}^{-1}\right)$, whereas $C$. mucunoides contained most $\mathrm{P}$ in Pedra Dourada. Lowest $\mathrm{P}$ concentrations were found in $A$. pintoi and $C$. mucunoides in Araponga and $S$. guianensis and S. aterrimum in Pedra Dourada. The $\mathrm{K}$ concentration did not differ among the legumes in Araponga. The $\mathrm{K}$ concentration was highest in $A$. pintoi and $C$. mucunoides and lowest in $S$. guianensis in Pedra Dourada. The Ca concentration was highest for $S$. guianensis and A. pintoi in Araponga and in Pedra Dourada. C. mucunoides had the lowest Ca concentration in Araponga and in Pedra Dourada. The $\mathrm{Mg}$ concentration was highest in A. pintoi in Araponga and in Pedra Dourada and lowest in C. mucunoides and $S$. aterrimum in Araponga and Pedra Dourada (Table 2).

In a comparison of the sites, $A$. pintoi and $C$. mucunoides contained different $\mathrm{P}$ and $S$. guianensis different $\mathrm{K}$ concentrations (Table 2). The amount of nutrients per hectare (Figure 1) differed among species and sites. But in Araponga, the highest amounts of $\mathrm{C}, \mathrm{N}, \mathrm{P}, \mathrm{K}, \mathrm{Ca}$, and $\mathrm{Mg}$ were found in $S$. aterrimum. In Pedra Dourada, the highest amounts of C, N, P, $\mathrm{K}, \mathrm{Ca}$, and $\mathrm{Mg}$ were observed for $S$. guianensis. In Araponga and in Pedra Dourada, the nutrient amounts of C, N, P, K, Ca were lowest in A. pintoi. $\mathrm{Mg}$ contents were lowest in Araponga and in $C$. mucunoides in Pedra Dourada. Comparing the sites, $S$. guianensis and $S$. aterrimum differed $(\mathrm{p}<0.05)$ in Araponga and Pedra Dourada. In Araponga the amounts of all nutrients (except $\mathrm{Mg}$ ) were higher for $S$. aterrimum and lower for $S$. guianensis than in Pedra Dourada. 
Table 2. Concentration of macronutrients in the biomass of green manure on farms in Araponga and Pedra Dourada

\begin{tabular}{|c|c|c|c|c|c|c|}
\hline Green manure & C & $\mathbf{N}$ & $\mathbf{P}$ & $\mathbf{K}$ & $\mathrm{Ca}$ & $\mathrm{Mg}$ \\
\hline & \multicolumn{6}{|c|}{$-\mathrm{g} \mathrm{kg}^{-1}$} \\
\hline & \multicolumn{6}{|c|}{ Araponga } \\
\hline A. pintoi & $408^{(1)}$ & $25.7 \mathrm{~B}$ & $2.4 \mathrm{bB}$ & 23.0 & $11.2 \mathrm{~A}$ & $4.5 \mathrm{~A}$ \\
\hline C. mucunoides & 421 & $30.9 \mathrm{AB}$ & $2.4 \mathrm{bB}$ & 22.4 & $8.2 \mathrm{~B}$ & $2.2 \mathrm{~B}$ \\
\hline S. guianensis & 431 & $29.5 \mathrm{~B}$ & $2.5 \mathrm{AB}$ & $23.0 \mathrm{a}$ & $11.3 \mathrm{~A}$ & $2.4 \mathrm{~B}$ \\
\hline \multirow[t]{2}{*}{ S. aterrimum } & 433 & $35.6 \mathrm{~A}$ & $2.8 \mathrm{~A}$ & 20.5 & $9.1 \mathrm{AB}$ & $2.2 \mathrm{~B}$ \\
\hline & \multicolumn{6}{|c|}{ Pedra Dourada } \\
\hline A. pintoi & 427 & $27.2 \mathrm{~B}$ & $2.7 \mathrm{aAB}$ & $22.6 \mathrm{~A}$ & $10.9 \mathrm{AB}$ & $5.0 \mathrm{~A}$ \\
\hline C. mucunoides & 441 & $35.2 \mathrm{~A}$ & $3.0 \mathrm{Aa}$ & $21.0 \mathrm{AB}$ & $8.3 \mathrm{~B}$ & $2.0 \mathrm{C}$ \\
\hline S. guianensis & 437 & $32.0 \mathrm{AB}$ & $2.6 \mathrm{~B}$ & $17.2 \mathrm{Bb}$ & $11.7 \mathrm{~A}$ & $2.5 \mathrm{~B}$ \\
\hline S. aterrimum & 453 & $37.0 \mathrm{~A}$ & $2.6 \mathrm{AB}$ & $19.7 \mathrm{AB}$ & $8.2 \mathrm{~B}$ & $2.0 \mathrm{C}$ \\
\hline
\end{tabular}

(1) Means followed by the same letters do not differ by the Tukey test $(\mathrm{p}<0.05)$. Capital letters compare green manures on the same farm and lower case letters compare the same organic manure among farms.

In the region where this research was carried out, nutrient accumulation and production of dry biomass of the four legume species are mainly affected by temperature changes, which is related to the altitude and the position of the fields relative to the sun. In our case, the field in Araponga faces West and the plot in Pedra Dourada South, so the daylight duration on the field in Araponga is longer, the soil drier, and the adapted plants tend to develop faster. The differences in nutrient content between locations for the same species can be attributed to the ability of each species to adapt to microclimatic conditions (Santos \& Campelo Júnior, 2003).

Of the four species, the dry biomass production and level of nutrient accumulation in the above-ground biomass of $S$. aterrimum was highest (Aita et al., 2000), improving soil fertility and biological conditions. The data obtained for $S$. aterrimum in Pedra Dourada are in agreement with those reported by Borkert et al. (2003), but the P, Ca and Mg concentrations were about $60 \%$ lower in Araponga. The biomass production of S. aterrimum may have been affected by factors such as the presence of ants, seed germination conditions and soil compaction (Oliveira et al., 2002). A. pintoi contained the lowest nutrient amounts, except for $\mathrm{Mg}$. This was related to the low biomass production and low nutrient absorption (Table 2). The high amounts of $\mathrm{Mg}$ in $A$. pintoi may have demonstrated a better mechanism of $A$. pintoi for $\mathrm{Mg}$ uptake from the soil than of the other species, although no data were found in the literature to support this hypothesis. The $\mathrm{N}$ amount in the dry biomass was much lower than reported by Soares et al. (2006). A. pintoi can produce $20 \mathrm{Mg}^{-1}$ of biomass per year and accumulate $520 \mathrm{~kg} \mathrm{ha}^{-1} \mathrm{~N}$ (Perin et al., 2003). S. guianensis and $C$. mucunoides contained intermediate amounts of nutrients. Little is known about nutrient contents in $S$. guianensis, because most research is focused on the species in association with grass (Andrade et al., 2003; Paciullo et al., 2003). S. guianensis and $C$. mucunoides have a yield potential of biomass of 8.2 and $7.5 \mathrm{Mg} \mathrm{ha}^{-1}$ year $^{-1}$ and accumulate 140 and $195 \mathrm{Mg}^{-1} \mathrm{~N}$, respectively (Niang et al., 2002; Muhr et al., 2002). The low values found for C. mucunoides in our study may have been caused by the shade falling on the growing plants under coffee plants and due to the measurements performed during the first year.

Considering the different potential of biomass production and nutrient content among the species, we propose that the best strategy for farmers to exploit the potential of each species is to use more than one green manure species in the system.

Biochemical characteristics of green manure

The biochemical composition varied among the four green manure species (Table 3). All species contained higher values of cellulose than of hemicellulose, followed by lignin and polyphenols. Among the green manures, $S$. guianensis contained lowest lignin amounts in Araponga and in Pedra Dourada, consequently, the lignin/N, lignin/polyphenol and (lignin+polyphenol)/ $\mathrm{N}$ ratios of this species were also low, indicating a high decomposition rate (Thomas \& Asakawa, 1993). These values are lower than those obtained by Monteiro et al. (2002), but this material remained in the field for a longer time, which resulted in higher lignin content.

The polyphenol concentration and polyphenol/N ratio in $C$. mucunoides were lowest and highest in $S$. aterrimum. Polyphenols have an important function in the biomass decomposition and $\mathrm{N}$ availability for soil microorganisms, due to the ability to complex $\mathrm{N}$ rapidly (Hättenschwiler \& Vitousek, 2000). Over longer periods, the content of cellulose, hemicellulose, lignin and $\mathrm{C} / \mathrm{P}, \mathrm{C} / \mathrm{N}$, lignin/ $\mathrm{N}$ ratios are more important than polyphenol content (Fox et al., 1990; Handayanto et al., 1995; Cobo et al., 2002a; Mendonça \& Stott, 2003). 
Table 3. Biochemical composition and C/P, C/N, LG/N, LG/PP and (LG + PP)/N ratios of green manures on farms in Araponga and Pedra Dourada

\begin{tabular}{|c|c|c|c|c|c|c|c|c|c|c|}
\hline Green manure & HM & CL & LG & $\mathbf{P P}$ & $\mathrm{C} / \mathrm{P}$ & $\mathrm{C} / \mathrm{N}$ & LG/N & LG/PP & $\mathbf{P P} / \mathbf{N}$ & $(\mathrm{LG}+\mathrm{PP}) / \mathrm{N}$ \\
\hline & \multicolumn{10}{|c|}{ Araponga } \\
\hline A. pintoi & 12.3 & 27.8 & 8.4 & 1.82 & 170 & 15.9 & 3.3 & 4.6 & 0.71 & 4.0 \\
\hline C. mucunoides & 12.4 & 28.2 & 7.8 & 1.19 & 175 & 13.6 & 2.5 & 6.6 & 0.38 & 2.9 \\
\hline S. guianensis & 12.7 & 32.3 & 6.1 & 1.54 & 172 & 14.6 & 2.1 & 4.0 & 0.52 & 2.6 \\
\hline \multirow[t]{2}{*}{ S. aterrimum } & 13.2 & 31.4 & 10.5 & 1.86 & 155 & 12.2 & 2.9 & 5.6 & 0.52 & 3.5 \\
\hline & \multicolumn{10}{|c|}{ Pedra Dourada } \\
\hline A. pintoi & 12.1 & 31.2 & 7.8 & 1.68 & 158 & 15.7 & 2.9 & 4.6 & 0.62 & 3.5 \\
\hline C. mucunoides & 16.6 & 26.7 & 9.0 & 1.30 & 147 & 12.5 & 2.6 & 6.9 & 0.37 & 2.9 \\
\hline S. guianensis & 12.9 & 29.8 & 4.8 & 1.72 & 168 & 13.6 & 1.5 & 2.8 & 0.54 & 2.0 \\
\hline S. aterrimum & 16.9 & 31.7 & 8.6 & 2.04 & 174 & 12.3 & 2.3 & 4.2 & 0.55 & 2.9 \\
\hline
\end{tabular}

HM: hemicellulose; CL: cellulose; LG: lignin; and PP: total soluble polyphenols.

\section{C-CO $\mathrm{CO}_{2}$ mineralization}

In the material from both sites, C- $\mathrm{CO}_{2}$ mineralization was highest for $A$. pintoi and $S$. guianensis (Figure 2). Based on the last four measurements of $\mathrm{C}-\mathrm{CO}_{2}$ mineralization, C- $\mathrm{CO}_{2}$ mineralization was higher for $A$. pintoi and $S$. guianensis than for $C$. mucunoides and $S$. aterrimum.

The residue characteristics cannot explain the differences of C- $\mathrm{CO}_{2}$ mineralization among the plant species (Table 4). However, $\mathrm{C}-\mathrm{CO}_{2}$ mineralization was positively correlated with $\mathrm{C}: \mathrm{N}$ and PP:N. Probably, the $\mathrm{N}$ amount was not limiting for decomposition and residues with lower $\mathrm{N}$ amounts and plants with a higher C:N ratio, such as $A$. pintoi, with higher values of $\mathrm{C}-\mathrm{CO}_{2}$ mineralization than the other species. In general, $\mathrm{C}: \mathrm{N}$ ratios below 30 do not affect microbial activity (Trinsoutrot et al., 2000). However, high $\mathrm{N}$ contents in the residues may initially contribute to increase $\mathrm{C}$ mineralization due to an increase of carbohydrate decomposition, but reduce the final mineralized C-CO (Wang et al., 2004). The mechanisms involved in this process may include suppression of the lignin enzyme activity (Carreiro et al., 2000), genesis of highly recalcitrant compounds involving $\mathrm{N}$ and lignin (Stevenson, 1994), genesis of compounds that are toxic to the soil microorganisms, such as polyphenols (Wang et al., 2004), and chemical protection of $\mathrm{N}$ compounds by their interaction with the soil mineral fraction (Baldock \& Skjemstad, 2000).

The C:P ratio did not have a negative effect on mineralized C-CO $\mathrm{CO}_{2}$, as observed by Mendonça \& Stott (2003), probably because such a low ratio is not expected to affect microbial activity (Stevenson, 1994).

The equation parameters (1) explaining $\mathrm{C}-\mathrm{CO}_{2}$ mineralization are given in table 5 . The "a"parameters of C- $\mathrm{CO}_{2}$ saturation were similar in the residues from both sites. However, the residues from Araponga had lower amounts of C- $\mathrm{CO}_{2}$ at the saturation point than the residues from Pedra Dourada $(p<0.05)$. This result may be a consequence of the variability in the chemical and biochemical characteristics of the residues (Tables 2 and 3) due to differences in the soil

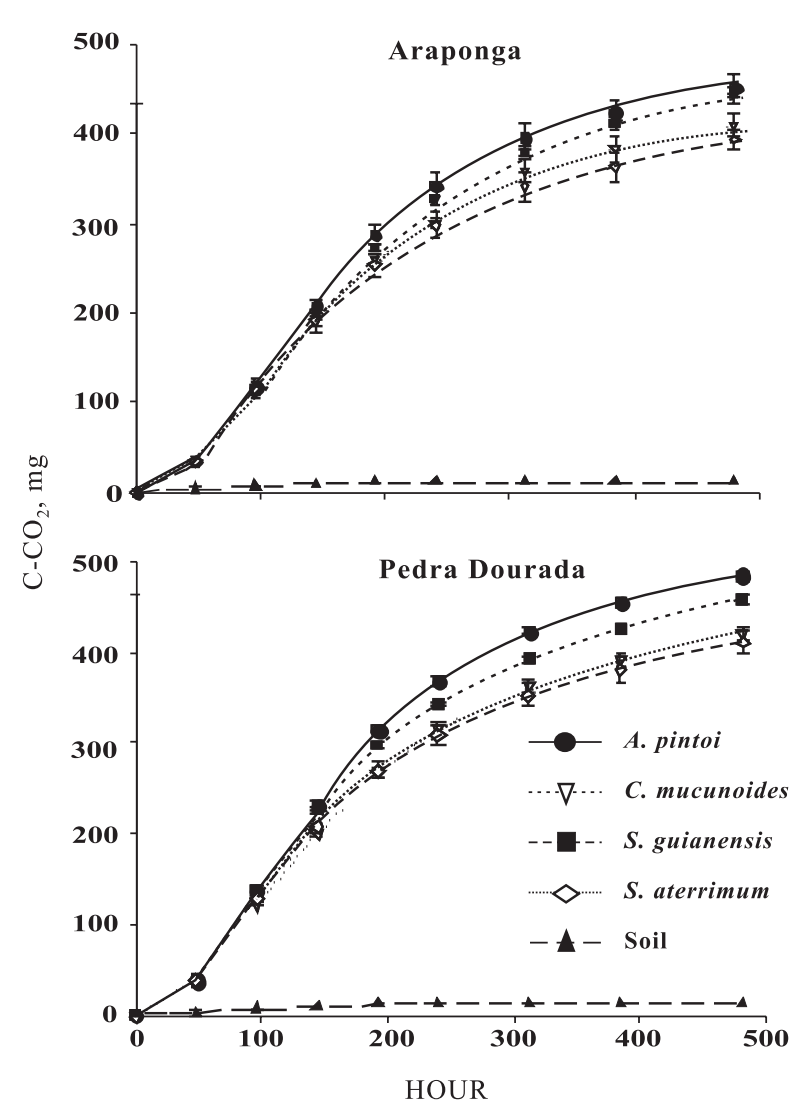

Figure 2. Amount of $\mathrm{C}-\mathrm{CO}_{2}$ mineralized by green manures on farms in Araponga and Pedra Dourada. Vertical bars represent the standard error $(n=4)$. 
Table 4. Correlation coefficients among $\mathrm{C}-\mathrm{CO}_{2}$ evolution and lignin (LG), polyphenols (PP) and C/P, C/N, LG/ $\mathrm{N}, \mathrm{LG} / \mathrm{PP}$ and $\mathrm{PP} / \mathrm{N}$ ratios $(\mathrm{n}=32)$

\begin{tabular}{|c|c|c|c|c|c|c|c|}
\hline \multirow{2}{*}{ Time } & \multicolumn{7}{|c|}{$\mathrm{C}-\mathrm{CO}_{2}$ evolution (mg) } \\
\hline & LG & PP & $\mathrm{C} / \mathrm{P}$ & $\mathrm{C} / \mathrm{N}$ & LG/N & LG/PP & $\mathbf{P P} / \mathbf{N}$ \\
\hline \multicolumn{8}{|l|}{$\mathrm{h}$} \\
\hline 48 & 0.051 & -0.023 & -0.359 & -0.180 & -0.066 & 0.118 & -0.149 \\
\hline 96 & -0.376 & 0.389 & -0.153 & 0.119 & -0.340 & $-0.567^{0}$ & 0.327 \\
\hline 144 & $-0.506^{0}$ & 0.298 & -0.044 & 0.489 & -0.206 & $-0.622^{*}$ & $0.517^{\circ}$ \\
\hline 192 & -0.496 & 0.201 & -0.014 & $0.711^{*}$ & -0.034 & $-0.559^{0}$ & $0.604^{0}$ \\
\hline 240 & -0.480 & 0.165 & -0.051 & $0.795^{* *}$ & 0.041 & $-0.535^{0}$ & $0.641^{*}$ \\
\hline 312 & $0.519^{0}$ & 0.036 & 0.031 & $0.867^{* *}$ & 0.057 & 0.471 & $0.588^{0}$ \\
\hline 384 & $-0.576^{0}$ & 0.035 & 0.040 & $0.838^{* *}$ & -0.022 & $-0.514^{0}$ & $0.563^{0}$ \\
\hline 480 & $-0.602^{0}$ & 0.051 & 0.034 & $0.821^{* *}$ & -0.064 & $-0.549^{0}$ & $0.561^{0}$ \\
\hline
\end{tabular}

and climatic characteristics of the localities (Thönnissen et al., 2000).

\section{$\mathbf{N}$ mineralization}

For all residues, $\mathrm{N}$ mineralization was highest in the first and seventh week after incubation (Table 6). In the other weeks, $\mathrm{N}$ immobilization predominated, especially until the fifth week, for residues from Araponga and the third week, for residues from Pedra Dourada. In residues with low $\mathrm{C} / \mathrm{N}$ ratios, $\mathrm{N}$ immobilization at the beginning of decomposition may be caused by $\mathrm{N}$ complexation by soluble polyphenols and lignin sub-products (Jensen, 1994; Trinsoutrot et al., 2000). The $\mathrm{N}$ released in the first week of incubation was negatively correlated $(p<0.01)$ with the polyphenol content and polyphenol: $\mathrm{N}$ ratios of the residues, as reported elsewhere (Palm \& Sanchez, 1991; Mafongoya et al., 2000; Cobo et al., 2002b).
Table 5. Logistic equation parameters $(a, b, c)$ of the $\mathrm{C}-\mathrm{CO}_{2}$ evolution and mean residence time $\left(\mathrm{t}_{1 / 2}\right)$ of green manures on farms in Araponga and Pedra Dourada

\begin{tabular}{|c|c|c|c|c|c|}
\hline Green manure & $A$ & $b$ & $C$ & $\mathbf{R}^{2}$ & $t_{1 / 2}$ \\
\hline & $\mathrm{mg} \mathrm{C}-\mathrm{CO}_{2}$ & & hour $^{-1}$ & & hour $^{-1}$ \\
\hline & & & ponga & & \\
\hline A. pintoi & 431.9 & -2.86 & 0.0184 & 0.996 & 155.5 \\
\hline C. mucunoides & 392.8 & -2.71 & 0.0173 & 0.995 & 156.2 \\
\hline S. guianensis & 425.2 & -2.77 & 0.0172 & 0.994 & 161.1 \\
\hline \multirow[t]{2}{*}{ S. aterrimum } & 372.7 & -2.68 & 0.0179 & 0.994 & 150.0 \\
\hline & \multicolumn{5}{|c|}{ Pedra Dourada } \\
\hline A. pintoi & 462.4 & -2.75 & 0.0182 & 0.994 & 151.7 \\
\hline C. mucunoides & 400.7 & -2.65 & 0.0174 & 0.994 & 152.5 \\
\hline S. guianensis & 433.1 & -2.66 & 0.0178 & 0.992 & 149.0 \\
\hline S. aterrimum & 387.8 & -2.59 & 0.0178 & 0.993 & 145.8 \\
\hline Soil & 11.7 & -2.60 & 0.0290 & 0.993 & 89.6 \\
\hline
\end{tabular}

Table 6. Nitrogen mineralized and immobilized $\left(\mathrm{NO}_{3}{ }^{-}+\mathrm{NH}_{4}{ }^{+}\right)$in green manure residues on farms in Araponga and Pedra Dourada after seven weeks

\begin{tabular}{|c|c|c|c|c|c|c|c|c|}
\hline \multirow{2}{*}{ Green manure } & \multicolumn{7}{|c|}{ Weeks } & \multirow{2}{*}{ Total $\mathbf{N}$ mineralized } \\
\hline & $1^{a}$ & 2 & & $3^{a}$ & $4^{a}$ & $5^{a}$ & $7^{a}$ & \\
\hline \multicolumn{9}{|c|}{$\begin{array}{c}\mathrm{NO}_{3}^{-}+\underset{\mathrm{NH}_{4}^{+}}{\text {Araponga }}\left(\mathrm{mg} \mathrm{kg}^{-1}\right) \\
\text { Arang }\end{array}$} \\
\hline $\begin{array}{l}\text { A. pintoi } \\
\text { C. mucunoides } \\
\text { S. guianensis } \\
\text { S. aterrimum }\end{array}$ & $\begin{array}{l}40.8 \mathrm{~b} \\
83.5 \mathrm{a} \\
72.8 \mathrm{ab} \\
66.8 \mathrm{ab}\end{array}$ & $\begin{array}{l}-57.2 \\
-16.1 \\
-68.7 \\
-66.8\end{array}$ & $\begin{array}{r}-35.0 \\
-7.3 \\
-44.5 \\
-36.3\end{array}$ & $\begin{array}{l}-5.4 \\
-7.2 \\
-8.3 \\
-3.4\end{array}$ & $\begin{array}{r}-1.1 \\
-33.1 \\
-1.4 \\
3.7\end{array}$ & $\begin{array}{c}44.4 \\
15.8 \\
6.6 \\
3.5\end{array}$ & $\begin{array}{l}51.5 \\
59.8 \\
60.0 \\
46.5\end{array}$ & $\begin{array}{l}137.4 \mathrm{a} \\
161.9 \mathrm{a} \\
111.6 \mathrm{a} \\
113.5 \mathrm{a}\end{array}$ \\
\hline $\begin{array}{l}\text { A. pintoi } \\
\text { C. mucunoides } \\
\text { S. guianensis } \\
\text { S. aterrimum } \\
\text { Soil }\end{array}$ & $\begin{array}{c}54.0 \mathrm{~b} \\
119.0 \mathrm{a} \\
57.8 \mathrm{~b} \\
46.8 \mathrm{~b} \\
9.3\end{array}$ & $\begin{array}{r}-99.8 \\
-36.8 \\
-99.9 \\
-67.2 \\
-3.7\end{array}$ & $\begin{array}{r}-26.7 \\
-27.9 \\
-29.1 \\
-28.5 \\
-7.4\end{array}$ & $\begin{array}{r}8.2 \\
16.6 \\
11.0 \\
9.1 \\
2.2\end{array}$ & $\begin{array}{r}\text { Pedra D } \\
20.1 \\
-29.3 \\
12.0 \\
-1.3 \\
1.8\end{array}$ & $\begin{array}{r}\text { ourada } \\
39.2 \\
52.9 \\
23.7 \\
27.6 \\
10.3\end{array}$ & $\begin{array}{r}68.3 \\
77.9 \\
103.2 \\
63.1 \\
16.5\end{array}$ & $\begin{array}{l}169.9 \mathrm{ab} \\
242.3 \mathrm{a} \\
176.4 \mathrm{ab} \\
136.9 \mathrm{~b} \\
46.9\end{array}$ \\
\hline
\end{tabular}

\footnotetext{
* Averages followed by the same letter in a column, to the same week and total mineralized N, do not differ by Tukey test $(\mathrm{p}>0.05)$.
} 
After the first week of incubation, $\mathrm{N}$ mineralization was higher in C. mucunoides residues from Araponga and Pedra Dourada than in the other green manures. After seven weeks, the total mineralized $\mathrm{N}$ was similar for all residues in Araponga. In Pedra Dourada, $C$. mucunoides mineralized more and $S$. aterrimum less $\mathrm{N}$ than the other residues. At the end of incubation, the residues from Pedra Dourada mineralized 38.4\% more $\mathrm{N}$ than the residues from Araponga. The total $\mathrm{N}$ mineralized was negatively correlated $(\mathrm{p}<0.05)$ with cellulose only. Mineralization after long incubation is affected by structural materials with low decomposition rate, such as cellulose (Hadas et al., 2004) and lignin (Palm \& Sanchez, 1991; Manfongoya et al., 1998).

\section{CONCLUSION}

In the short term, $\mathrm{N}$ mineralization of green manure residues was controlled by the polyphenol content and polyphenols/ $\mathrm{N}$ ratio, and in the long term, cellulose was the main factor.

In the Zona da Mata, region Southeastern Brazil, the nutrient accumulation, the biochemical characteristics and biomass production of Arachis pintoi, Calopogonium mucunoides, Stizolobium aterrimum and Stylosanthes guianensis are affected by temperature changes, related to the altitude and the position of the agricultural area relative to the sun.

A. pintoi, $C$. mucunoides, $S$. aterrimum and $S$. guianensis are highly promising to improve nutrient cycling and as green manure for coffee.

\section{ACKNOWLEDGMENTS}

We thank the farmers "Jésus" and "Dadinho" for their interactive participation in the field work as well as the FAPEMIG (Research Foundation of Minas Gerais State) for financial support and CAPES for a scholarship to E.S. Matos.

\section{LITERATURE CITED}

AITA, C.; FRIES, M.R. \& GIACOMINI, S.J. Ciclagem de nutrientes no solo com plantas de cobertura e dejetos de animais. In: FERTBIO, 25., Santa Maria, 2000. Anais. Santa Maria, Sociedade Brasileira de Ciência do Solo, 2000. CD-ROM.

ANDERSON, J.D. \& INGRAM, J.S.I. Tropical soil biology and fertility: A handbook of methods. 2.ed. Wallingford, UK CAB International, 1996. 171p.
ANDRADE, C.M.S.; GARCIA, R.; COUTO, L.; PEREIRA, O.G. \& SOUZA, A.L. Desempenho de seis gramíneas solteiras ou consorciadas com o Stylosanthes guianensis cv. Mineirão e eucalipto em sistema silvipastoril. R. Bras. Zootec., 32:1845-1850, 2003.

BALDOCK, J.A. \& SKJEMSTAD, J.O. Role of soil matrix and minerals in protecting natural organic materials against biological attack. Org. Geochem., 31:697-710, 2000.

BORKERT, C.M.; GAUDÊNCIO, C.A.; PEREIRA, J.E.; PEREIRA, L.R. \& OLIVEIRA JUNIOR, A. Nutrientes minerais na biomassa da parte aérea em culturas de cobertura de solo. Pesq. Agropec. Bras., 38:143-153, 2003.

BRAGA, J.M. \& DEFELIPO, B.V. Determinação espectrofotométrica de fósforo em extratos de solo e planta. R. Ceres, 21:73-85, 1994.

CABRERA, M.L.; KISSEL, D.E. \& VIGIL, M.F. Nitrogen mineralization from organic residues: Research opportunities. J. Environ. Qual., 34:75-79, 2005.

CARREIRO, M.M.; SINSABAUGH, R.L.; REPERT, D.A. \& PARKHURST, D.F. Microbial enzyme shifts explain litter decay response to simulated nitrogen deposition. Ecology, 81:2359-2365, 2000.

COBO, J.G.; BARRIOS, E.; KASS, D.C.L. \& THOMAS, R.J. Decomposition and nutrient release by green manure in a tropical hillside agroecosystem. Plant Soil, 240:331-342, 2002a.

COBO, J.G.; BARRIOS, E.; KASS, D.C.L. \& THOMAS, R.J. Nitrogen mineralization and crop uptake from surfaceapplied leaves of green manure on a tropical volcanic-ash soil. Biol. Fert. Soils, 36:87-92, 2002b.

CURL，E.A. \& RODRIGUEZ-KABANA，R. Microbial interactions. In: WILKINSON, R.E. Research methods in weed science. Atlanta, Southern Weed Society, 1972. p.162-194.

FERRARI, E.A. Desenvolvimento da agricultura familiar: a experiência do CTA-ZM. In: ALVAREZ V., V.H.; FONTES, L.E.F. \& FONTES, M.P.F., eds. O solo nos grandes domínios morfoclimáticos do Brasil e o desenvolvimento sustentado. Viçosa, MG, 1996. p.233-250.

FOX, R.H.; MYERS, R.J.K. \& VALLIS, I. The nitrogen mineralization rate of legume in soil as influenced by their polyphenol, lignin and nitrogen contents. Plant Soil, 129:251-259, 1990.

FUNARBE. SAEG - Sistema para análises estatísticas v. 5.0. Viçosa, MG, 1993.

HADAS, A.; KAUTSKY, L.; GOEK, M. \& KARA, E.E. Rates of decomposition of plant residues and available nitrogen in soil, related to residue composition through simulation of carbon and nitrogen turnover. Soil Biol. Biochem., 36:255$266,2004$.

HANDAYANTO, E.; CADISCH, G. \& GILLER, K.E. Manipulation of quality and mineralization of tropical legume tree prunings by varying nitrogen supply. Plant Soil, 176:149-160, 1995. 
HÄTTENSCHWILER, S. \& VITOUSEK, P.M. The role of polyphenols in terrestrial ecosystem nutrient cycling. Tree, 15:238-243, 2000.

JENSEN, E.S. Mineralization-immobilization of nitrogen in soil amended with low $\mathrm{C} / \mathrm{N}$ ratio plant residues with different particle size. Soil Biol. Biochem, 26:519-521, 1994 .

KEMPERS, A.J. \& ZWEERS, A. Ammonium determination in soil extracts by the salicylate method. Comm. Soil Sci. Plant Anal., 17:715-723, 1986.

MAFONGOYA, P.L.; NAIR, P.K.R. \& DZOWLA, B.H Mineralization of nitrogen from decomposing leaves of multipurpose trees as affected by their chemical composition. Biol. Fert. Soils, 27:143-148, 1998.

MAFONGOYA, P.L.; BARAK, P. \& REED, J.D. Carbon, nitrogen and phosphorus mineralization of tree leaves and manure. Biol. Fert. Soils, 30:298-305, 2000.

MENDONÇA, E.S. \& STOTT, D.E. Characteristics and decomposition rates of pruning residues from a shaded coffee system in Southeastern Brazil. Agrofor. Syst., $57: 117-125,2003$.

MONTEIRO, H.C.F.; CANTARUTTI, R.B.; NASCIMENTO JR, D.; REGAZZI, A.J. \& FONSECA, D.M. Dinâmica de decomposição e mineralização de nitrogênio em função da qualidade de resíduos de gramíneas e leguminosas forrageiras. R. Bras. Zootec., 31:1092-1102, 2002.

MORGAN, P.H.; MERCER, L.P. \& FLODIN, N.W. General model for nutritional responses of higher organisms. Proc. Nat. Acad. Sci. 72:4327-4331, 1975.

MUHR, L.; TARAWALI, S.A.; PETERS, M. \& SHULTZEKRAFT, R. Soil mineral N dynamics and grain yields following Centrosema macrocarpum and Stylosanthes guianensis: Effects of different rotations and varying levels of N fertiliser. Field Crops Res., 78:197-209, 2002.

NIANG, A.I.; AMADALO, B.A.; WOLF, J. \& GATHUMBI, S.M. Species screening for short-term planted fallows in the highlands of Western Kenya. Agrofor. Syst., 56:145-154, 2002 .

OLIVEIRA, T.K.; CARVALHO, G.J. \& MORAES, R.N.S. Plantas de cobertura e seus efeitos sobre o feijoeiro em plantio direto. Pesq. Agropec. Bras., 37:1079-1087, 2002.

PACIULLO, D.S.C.; AROEIRA, L.J.M.; ALVIM, M.J. \& CARVALHO, M.M. Características produtivas e qualitativas de pastagem de braquiária em monocultivo e consorciada com estilosantes. Pesq. Agropec. Bras., 38:421-426, 2003.

PALM, C.A. \& SANCHEZ, P.A. Nitrogen release from the leaves of some tropical legumes as affected by their lignin and polyphenol contents. Soil Biol. Biochem., 23:83-88, 1991.
PERIN, A.; GUERRA, J.G.M. \& TEIXEIRA, M.G. Cobertura do solo e acumulação de nutrientes pelo amendoim forrageiro. Pesq. Agropec. Bras., 38:791-796, 2003.

SÁ, N.M.H. \& VARGAS, M.A.T. Fixação biológica de nitrogênio por leguminosas forrageiras. In: VARGAS, M.A.T. \& HUNGRIA, M., eds. Biologia dos solos dos cerrados. Planaltina, Embrapa-CPAC, 1997. p.127-152.

SANTOS, V.S. \& CAMPELO JÚNIOR, J.H. Influência dos elementos meteorológicos na produção de adubos verdes, em diferentes épocas de semeadura. R. Bras. Eng. Agríc. Amb., 7:91-98, 2003.

SARRUGE, J.R. \& HAAG, H.P. Análises químicas em plantas. Piracicaba, Escola Superior de Agricultura "Luiz de Queiroz", 1974. 56p. (Boletim Técnico)

SOARES, P.G.; RESENDE, A.S.; URQUIAGA, S.; CAMPELLO, E.F.C. \& FRANCO, A.A. Estabelecimento, produção de fitomassa, acúmulo de macronutrientes e estimativa da fixação biológica de nitrogênio em Arachis. Past. Tropic., 28:18-25, 2006.

STEVENSON, F.J. Humus chemistry: Genesis, composition, reactions. 2.ed. New York, John Wiley, 1994. 496p.

THOMAS, R.J. \& ASAKAWA, N.M. Decomposition of leaf litter from tropical forage grasses and legumes. Soil Biol. Biochem., 25:1351-1361, 1993.

THÖNNISSEN, C.; MIDMORE, D.J.; LADHA, J.K.; OLK, D.C. \& SCHMIDHALTER, U. Legume decomposition and nitrogen release when applied as green manures to tropical vegetable production systems. Agron. J., 92:253260,2000 .

TRINSOUTROT, I.; RECOUS, S.; BENTZ, B.; LINÈRES, M.; CHÈNEBY, D. \& NICOLARDOT, B. Biochemical quality of crop residues and carbon and nitrogen mineralization kinetics under nonlimiting nitrogen conditions. Soil Sci. Soc. Am. J., 64:918-926, 2000.

van SOEST, P.J.; ROBERTSON, J.B. \& LEWIS, B.A. Methods for dietary fiber, neutral detergent fiber, and nonstarch polysaccharides in relation to animal nutrition. J. Dairy Sci., 74:3583-3597, 1991.

WANG, W.J.; BALDOCK, J.A.; DALAL, R.C. \& MOODY, P.W. Decomposition dynamics of plant materials in relation to nitrogen availability and biochemistry determined by NMR and wet-chemical analysis. Soil Biol.Biochem., $36: 2045-2058,2004$.

YANG, J. E.; SKOGLEY, E.O.; SCHAFF, B.E. \& KIM, J.J. A simple spectrometric determination of nitrate in water, resin, and soil extracts. Soil Sci. Soc. Am. J., 62:11081115, 1998. 